\title{
HUBUNGAN MOTIVASI KERJA TERHADAP KINERJA GURU DI SEKOLAH DASAR
}

\author{
Wayan Satria Jaya \\ STKIP PGRI Bandar Lampung \\ wayansatriajaya@gmail.com
}

\begin{abstract}
Abstrak
Kinerja guru sebagai tenaga professional dibidang pendidikan, guru hendaknya memiliki motivasi yang tinggi dalam melaksanakan tugas kependidikan dan keguruannya banyak hal yang dapat menimbulkan motivasi kerja guru yang rendah. motivasi kerja guru yang tinggi akan dapat meningkatkan kepuasan kerja. dengan adanya kepuasan kerja, guru akan berkontribusi terhadap kinerjanya. penelitian ini berupaya untuk melihat apakah terdapat hubungan antara motivasi kerja dengan kinerja guru sekolah dasar. Secara khusus penelitian ini bertujuan untuk mengetahui hubungan antara motivasi dengan kinerja guru sekolah dasar. Metode yang digunakan dalam penelitian ini adalah metode deskriptif korelasional dengan menggunakan pendekatan kuantitatif, yaitu menggambarkan atau mendeskripsikan pengaruh motivasi kerja dengan kinerja guru di sekolah dasar. Metode deskriptif korelasional ini berasaskan pada pencarian ilmiah berdasarkan pada asas-asas tertentu. Berdasarkan analisis korelasi antara motivasi kerja dengan kinerja guru diperoleh nilai $t$-hit sebesar 5,083. Dari hasil penghitungan diperoleh nilai $t$-hit adalah $5.083 \geq$ nilai $t$-tab adalah 2.068 ; lalu $\mathrm{H} 0$ ditolak dan $\mathrm{H} 1$ diterima. Dengan demikian dapat disimpulkan terdapat pengaruh motivasi kerja dengan kinerja guru.
\end{abstract}

Kata Kunci: Motivasi Kerja, Kinerja Guru

\section{PENDAHULUAN}

Seiring dengan kemajual ilmu pengetahuan dan teknologi, tantangan dunia pendidikan ke depan menimbulkan sejumlah tantangan besar khususnya bagi tenaga pendidik. Tenaga pendidik atau guru harus mempunyai kemampuan adaptif terhadap berbagai perubahan serta harus memiliki motivasi yang tinggi untuk menjalankan system pendidikan di negeri ini. Tidak dapat dipungkiri bahwa perubahan yang dapat terjadi di setiap saat dapat emmpengaruhi semangat, daya juang serta motivasi guru dalam menjalankan kewajibannya sebagai tenaga pendidik yang mempunyai tugas mencerdaskan kehidupan anak-anak bangsa. Kualitas pendidikan di Indonesia harus selalu ditingkatkan dalam rangka menyiapkan sumber daya manusia yang berkualitas seperti yang terkandung dalam tujuan pendidikan. Peningkatan kualitas pendidikan tentunya harus didukung dengan adanya kualitas tenaga mengajar. Kualitas tenaga kependidikan juga merupakan sumber daya yang ada dalam lembaga kependidikan. Menurut Sahertien (2010:1) dalam usaha meningkatkan kualitas sumber daya pendidikan, guru merupakan komponen sumber daya manusia yang harus dibina dan dikembangkan terus menerus. Hal ini diperkuat oleh pendapat Mulyasa (2013:5) yang mengungkapkan bahwa komponen paling menentukan dalam sistem pendidikan adalah guru, sehingga harus mendapat perhatian yang utama. Seorang 
guru harus dapat menyesuaikan diri dengan adanya perkembangan ilmu pengetahuan dan tekonologi yang cepat, karena guru harus menjalankan fungsinya secara profesional.

Dalam pandangan masyarakat modern, guru belum merupakan profesi yang profesional jika hanya mampu membuat murid membaca, menulis, dan berhitung, atau mendapatkan nilai tinggi, naik kelas dan lulus ujian. Masyarakat modern menganggap kompetensi guru belum lengkap jika hanya dilihat dari keahlian dan keterampilan yang dimiliki, melainkan juga dari orientasi guru terhadap perubahan dan inovasi. Bagi masyarakat moderen, eksisensi guru yang mandiri, kreatif, dan inovatif merupakan salah satu aspek paling penting untuk membangun kehidupan bangsa.

Guru memiliki peran yang penting dan strategis, dan bertanggungjawab dalam usaha pencapaian tujuan pendidikan nasional. Usman (2009: 7) menyatakan bahwa tugas guru sebagai profesi meliputi mendidik, mengajar, dan melatih. Mendidik berarti meneruskan dan mengembangkan nilai-nilai hidup, sedangkan mengajar berarti meneruskan, mengembangkan ilmu pengetahuan, dan teknologi. Melatih berarti mengembangkan keterampilan-keterampilan pada siswa. Senada dengan Usman, Suyanto dan Hisyam (2000:27) menyatakan bahwa guru merupakan pihak yang paling sering dituding sebagai orang yang paling bertanggung jawab terhadap kualitas pendidikan. Hal ini berarti bahwa kehadiran dan profesionalisme seorang guru sangat berpengaruh dalam menentukan dan mewujudkan cita-cita pembangunan nasional terutama mewujudkan program pendidikan nasional. Dengan demikian, peranan guru sangat menentukan dalam usaha peningkatan mutu pendidikan formal. Untuk itu guru sebagai agen pembelajaran dituntut untuk mampu menyelenggarakan proses pembelajaran dengan sebaikbaiknya, dalam kerangka pembangunan pendidikan. Karena guru mempunyai fungsi dan peran yang sangat strategis dalam pembangunan bidang pendidikan, maka profesi guru perlu dikembangkan sebagai profesi yang bermartabat.

Dalam upaya memenuhi kebutuhan guru untuk menjadi guru profesional, guru haruslah memiliki motivasi kerja yang sangat tinggi. Motivasi kerja guru tidak lain merupakan proses yang dilakukan untuk menggerakan guru agar perilaku guru dapat diarahkan pada upaya-upaya yang nyata untuk mencapai tujuan pembelajaran. Apabila para guru mempunyai motivasi kerja yang tinggi, mereka akan terdorong dan berusaha meningkatkan kemampuannya dalam merencanakan, melaksanakan, dan mengevaluasi kurikulum yang berlaku disekolah sehingga memperoleh hasil kerja yang maksimal. Hal tersebut dapat dikatakan bahwa seorang guru sudah cukup professional dalam menjalani perannya sebagai seorang guru.

Tugas seorang guru memanglah berat, selain menjadi seorang pendidik guru juga harus menjadi manajer yang akan mengatur segala sesuatu yang berhubungan dengan administrasi pembelajaran di dalam kelas. Mulai dari perencanaan, pengorganisasian, pengendalian, dan evaluasi pembelajaran yang telah dilakukan oleh guru dalam proses pembelajaran. Menurut Djamarah (2011:149) ada dua macam motivasi yaitu motivasi yang berasal dari dalam pribadi seseorang dan berasal dari luar diri seseorang. Jika seorang guru tidak memiliki profesionalitas yang tinggi maka, kinerja yang diciptakan tidak akan berjalan optimal. Menurut Sedarmayanti (Supardi, 2013:19): Kinerja guru merupakan kemampuan dan keberhasilan guru dalam melaksanakan 
tugas-tugas pembelajaran. Kinerja guru dipengaruhi oleh beberapa faktor. Faktor yang mempengaruhi kinerja antara lain: (1) sikap mental (motivasi kerja, disiplin kerja, etika kerja); (2) pendidikan; keterampilan; (4) manajemen kepemimpinan; (5) tingkat penghasilan; (6) gaji dan kesehatan; (7) jaminan sosial; (8) iklim kerja; (9) sarana prasarana; (10) teknologi; (11) kesempatan berprestasi. Motivasi kerja bukan timbul dari dalam diri guru saja melainkan juga dari kekuatankekuatan lingkungan yang mempengaruhi guru untuk melakukan sesuatu berdasarkan tujuan tujuan yang telah ditetapkan sebelumnya untuk dicapai. Faktor motivasi sangat berperan dalam tercapainya peningkatan profesionalisme guru.

Berdasarkan kenyataan dilapangan kurang maksimalnya dan kurang produktifnya pekerjaan dari guru Sekolah Dasar dalam melakukan tugasnya. Hal ini dapat dilihat dari masih adanya guru yang sering menunda-nunda pekerjaan, hadir terlambat pada waktu yang telah ditetapkan dan pada jam kerja beberapa guru tidak pada posisinya dengan alasan yang tidak jelas ataupun meninggalkan kantor sebelum jam kerja berakhir. Selain itu tingkat kehadiran guru yang belum dapat dikatakan baik, hal ini akan berakibat tidak baik bagi sekolah, karena banyak waktu yang tidak terpakai dengan baik. Hal lain yang dapat dilihat berdasarkan observasi yaitu dalam melaksanakan pekerjaan ada kalanya guru tidak memiliki displin kerja yang tinggi dan melakukan penyimpangan dalam melaksanakan tugasnya khususnya bila pimpinan tidak berada ditempat dan mereka keluar untuk kepentingan diluar pekerjaan tanpa sepengetahuan pimpinan, sehingga banyak menyebabkan banyak pekerjaan tertinggal.
Pada sisi lain, tidak sedikit pula guru yang kurang memahami bidang tugasnya. Terutama mereka yang tidak mampu mengikuti perkembangan terbaru, perkembangan di dunia pendidikan, baik yang berhubungan dengan metode dan teknik, maupun yang berhubungan dengan disiplin ilmunya. Kegairahannya berkurang karena merasa selalu tertinggal, merasa tidak mampu mengaktualisasikan diri mereka dihadapan anak didik, dihadapan rekanrekan lain. Ada guru yang kurang menguasai bahan ajar untuk mata pelajaran tertentu dan terkesan terpaksa mengajar karena system guru kelas. Keadaan seperti ini turut mempengaruhi kemampuan dan kualitas kerja guru, dan berdampak pada mutu pendidikan. Diketahui pula bahwa sebagian guru tidak menguasai bahan yang akan diajarkan sehingga peserta didik hanya disuruh mencatat atau mengerjakan tugastugas. Terdapat guru yang tidak mempunyai bahan ajar yang ditulisnya (buku pegangan) sehingga guru yang bersangkutan merasa tidak percaya diri dan dalam menerapkan pembelajaran tidak efektif dan kondusif. Sebagian guru tidak menguasai landasan kependidikan, tidak mampu melaksanakan fungsi dan tugas sebagai pendidik dan pengajar. Terdapat guru yang tidak mempersiapkan apa yang akan diajarkan. Dengan keadaan yang demikian, maka peserta didik cenderung tidak tertarik untuk belajar dengan sungguh-sungguh atau menjadi malas. Di samping itu, ditemukan sebagian guru mempunyai motivasi kerja yang rendah, kurang memiliki inisiatif dan kurang kreatif dalam mengadakan dan menulis bahan ajar, kurang produktif, kurang supel dalam pergaulan dan kurang informative sehingga tidak dapat mengakses di mana-mana serta jarang memperoleh tugas-tugas tambahan dari kepala sekolah. 
Motivasi adalah kekuatan dalam diri
individu yang mendorong dan menggerakkan individu melakukan kegiatan mencapai suatu tujuan (Sukmadinata, 2007). Supriyatin (2013) berpendapat bahwa motivasi adalah sebuah istilah umum yang diterapkan kepada seluruh anggota kelompok yang mengarahkan, menimbulkan keinginan, kebutuhan, keinginan yang kuat serta dorongan yang sejenis. Dengan definisi yang singkat, Dale H. Schunk (2012) berpendapat bahwa motivasi merupakan suatu proses dimulainya dan dipertahankannya aktivitas yang diarahkan terhadap pencapaian tujuan yang telah ditentukan sebelumnya. Menurut Hamzah B. Uno (2012) motivasi dapat dikatakan sebagai kekuatan, baik dari dalam maupun dari luar yang membuat seseorang terdorong untuk mencapai suatu tujuan tertentu yang telah ditentukan sebelumnya. motivasi merupakan dorongan yang terdapat dalam diri seorang individu untuk berusaha mengadakan perubahan tingkah laku yang lebih baik dalam rangka memenuhi kebutuhannya. Kinerja guru adalah kompetensi dan hasil kerja guru dalam melaksanakan tugas utamanya seperti mendidik, megajar, membimbing, mengarahkan, melatih, menilai dan mengevaluasi hasil pembelajaran siswa dan diukur dengan standar yang sudah ditetapkan. Dalam meningkatkan produktivitas sekolah tidak hanya berbicara tentang kuantitas atau hasil kerja sebanyakbanyaknya, tetapi juga berbicara tentang kualitas dari hasil kerja itu sendiri. Kinerja guru tidak terwujud dengan begitu saja, tetapi dipengaruhi oleh faktor-faktor tertentu. Baik faktor internal maupun faktor eksternal samasama membawa dampak terhadap kinerja guru. Faktor internal kinerja guru adalah faktor yang datang dari dalam diri guru yang dapat mempengaruhi kinerjanya, seperti kemampuan, keterampilan, kepribadian, persepsi, motivasi menjadi guru, pengalaman lapangan dan latar belakang keluarga. Faktor eksternal kinerja guru adalah faktor yang datang dari luar guru yang dapat mempengaruhi kinerjanya, seperti gaji, sarana dan prasaraha, lingkungan kerja fisik dan kepemimpinan (Widiastuti dkk: 2017).

Berdasarkan beberapa penelitian yang relevan berkaitan dengan motivasi dan kinerja guru dilakukan oleh beberapa peneliti diantaranya adalah Cici Asterya Dewi dengan jurul Pengaruh Motivasi Kerja Terhadap Kinerja Guru Honorer (Studi Kasus Guru Honorer SMAN Rumpun IPS Se-Kecamatan Temanggung). Berdasarkan analisis data mengenai pengaruh motivasi kerja (X) dan kinerja guru honorer (Y) di SMAN Rumpun IPS Se-Kecamatan Temanggung dapat diambil kesimpulan motivasi kerja berpengaruh positif dan signifikan terhadap kinerja guru honorer. Hasil penelitian diketahui motivasi kerja menghasilkan koefisien regresi 0,381 dan tingkat signifikan sebesar $0,038<0,05$. Untuk koefisien determinasi diperoleh angka koefisien R Square sebesar 0,146. Hal ini berarti bahwa sebesar $14,6 \%$ dapat dijelaskan oleh motivasi kerja terhadap kinerja guru honorer. Sedangkan sisanya $85,4 \%$ dijelaskan oleh sebab-sebab yang lain di luar variabel motivasi kerja. Selanjutnya dilaksanakan oleh Eri Agustin dengan judul Pengaruh Motivasi Kerja Terhadap Kinerja Guru Sekolah Dasar Dabin IV Kecamatan Kajen Kabupaten Pekalongan. Berdasarkan analisis data, pengujian hipotesis yang meliputi uji korelasi, uji regresi sederhana dan koefisien determinasi serta hasil pembahasan yang telah dikemukakan oleh peneliti, maka dapat diambil kesimpulan adanya pengaruh motivasi kerja terhadap kinerja guru Sekolah Dasar di Dabin IV 
Kecamatan Kajen Kabupaten Pekalongan. Nilai koefisien korelasi yang dihasilkan sebesar 0,664 yang artiya bahwa motivasi kerja memiliki hubungan yang kuat. Jamaris (2013:170) menyatakan bahawa motivasi adalah suatu tindakan yang menggerakkan dan memilih untuk melakukan suatu perbuatan kearah tujuan yang akan dicapai. Sedangkan menurut Uno (2010:10) yang dimaksud dengan motivasi adalah dorongan internal dan eksternal dalam diri seseorang untuk mengadakan perubahan tingkah lakul, yang mempunyai indikator sebagai berikut: (1) adanya hasrat dan keinginan untuk melakukan kegiatan, (2) adanya dorongan dan kebutuhan melakukan kegiatan, (3) adanya harapan dan cita-cita, penghargaan dan penghormatan atas diri, (5) adanya lingkungan yang baik, dan (6) adanya kegiatan yang menarik.

Zainun (2004:17) mengungkapkan bahwa motivasi merupakan gambaran hubungan antara harapan yang dimiliki seseorang atau organisasi dengan tujuan yang telah ditentukan karena setiap orang memiliki suatu tujuan dalam kegiatannya. Hubungan antara harapan dengan tujuan ini beranekaragam dan selalu bertambah, baik secara vertikal maupun horisontal. Gambaran mengenai hubungan ini tentu dipengaruhi oleh banyak faktor, baik dari dalam maupun faktor dari luar. Harapan ini dapat tercapai atau tidaknya tergantung dengan bagaimana usaha dari individu tersebut berusaha untuk mencapainya. dengan kinerja guru yang dihasilkan. Besarnya pengaruh motivasi kerja terhadap kinerja guru ialah sebesar 44,1\%, sedangkan sisanya 55,9\% kinerja guru dipengaruhi oleh faktorfaktor lain di luar motivasi kerja. Berdasarkan pemaparan di atas, keterkaitan antara motivasi kerja, masa kerja dan kesejahteraan guru dengan profesionalisme guru sekolah dasar sangatlah erat. Hal inilah yang menjadi latar belakang penelitian tentang hubungan motivasi kerja terhadap kinerja Guru Sekolah Dasar. Penelitian ini bertujuan untuk mengetahui hubungan motivasi kerjaterhadap kinerja guru guru Sekolah Dasar.

\section{METODE}

Metode yang digunakan dalam penelitian ini adalah metode deskriptif korelasional dengan menggunakan pendekatan kuantitatif, yaitu menggambarkan atau mendeskripsikan pengaruh motivasi kerja dengan kinerja guru di Sekolah Dasar. Metode deskriptif korelasional ini berasaskan pada pencarian ilmiah berdasarkan pada asas-asas tertentu. Metode yang digunakan dengan mendeskripsikan atau menggambarkan suatu fenomena yang ada. Tujuan dari penelitian deskriptif korelasional ialah untuk menjelaskan hubungan variabel bebas (X) dengan variabel terikat $(\mathrm{Y})$.

Sampel pada penelitian ini ditentukan dengan menggunakan rumus (Sugiyono: 2009):

$$
\mathrm{n}=\frac{N}{1+N e^{2}}
$$

Keterangan:

$\mathrm{n}=$ sampel $\mathrm{N}=$ populasi $\mathrm{e}=$ perkiraan tingkat kesalahan

Populasi di dalam penelitian adalah seluruh dewan guru Sekolah Dasar. Jumlah populasi total di dalam penelitian ini berjumlan 35 orang.

Pengumpulan data merupakan suatu proses pengadaan data untuk keperluan suatu penelitian yang merupakan langkah penting dalam metode ilmiah, maka dari itu pengumpulan data sangat diperlukan di dalam suatu penelitian. Di dalam penelitian ini, peneliti menggunakan beberapa teknik pengumpulan data, diantaranya Kuesioner dan Studi Dokumentasi. Instrumen 
Penelitian yng digunakan dalam penelitian ini adalah menggunakan angket. Di dalam penelitian ini skala yang digunakan variabel kinerja guru adalah model skala likert. Skala likert memiliki alternatif jawaban sebanyak lima buah dan masing-masing diberikan skor sebagai berikut:

\section{Tabel 1}

Skala Motivasi Kerja

\begin{tabular}{|l|l|l|}
\hline \multirow{2}{*}{ Alternatif Jawaban } & \multicolumn{2}{c|}{ Bobot nilai } \\
\cline { 2 - 3 } & Positif & Negatif \\
\hline Selalu (SL) & 5 & 5 \\
\hline Sering (SR) & 4 & 4 \\
\hline Kadang-kadang (KD) & 3 & 3 \\
\hline Pernah (P) & 2 & 2 \\
\hline Tidak Pernah (TP) & 1 & 1 \\
\hline
\end{tabular}

Dalam menentukan validitas suatu instrumen digunkan rumus Product Moment. Sedangkan teknik analisis data Statistik Deskriptif yang digunakan untuk menganalisis data dengan cara mendeskripsikan atau menggambarkan data yang telah terkumpul dengan apa adanya tanpa bermaksud membuat kesimpulan yang berlaku untuk umum atau generalisasi. Termasuk dalam statistik deskriptif antara lain penyajian data melalui tabel, grafik, diagram lingkaran, pictogram, perhitungan modus, median, mean (pengukuran tendensi sentral), perhitungan desil, persentil, perhitungan penyebaran data melalui perhitungan rata-rata dan standar deviasi, perhitungan persentase. Data yang telah berhasil peneliti kumpulkan diringkas dan dihubungkan kaitannya dengan variabel penelitian yang bersangkutan.

\section{HASIL PENELITIAN}

Dalam penelitian ini data yang dikumpulkan terdapat dua variabel yang berkaitan, yaitu Motivasi Kerja sebagai variabel bebas (variabel $\mathrm{X}$ ) dan Kinerja guru sebagai variabel terikat (variabel Y).

\section{Deskripsi Data Penelitian}

Uraian di bawah ini menyajikan data dua variabel ukur, yaitu data Motivasi Kerja (X) dan Kinerja Guru (Y). Variabel motivasi kerja (X) diperoleh dari hasil penyebaran angket dengan skor terlampir dari masing-masing responden. Sedangkan variabel kinerja guru (Y) juga diperoleh dari penyebaran angket terlampir. Selanjutnya data tersebut diolah serta dideskripsikan secara singkat dan jelas demi memaparkan hasil dari perhitungan secara statistik agar memperoleh gambaran yang utuh. Berikut tampilah hasil perhitungan dasar statistik dari kedua variabel tersebut.

\section{a. Deskripsi Data Motivasi Kerja}

Tabel 2

Deskripsi Data Variabel Motivasi Kerja

\begin{tabular}{|c|c|}
\hline $\begin{array}{lc}\text { Jumlah } & \text { Statistic } \\
\mathrm{N} & \text { Valid } \\
& \text { Missing } \\
\text { Mean } & \\
\text { Median } & \\
\text { Mode } & \\
\text { Std. Deviation } \\
\text { Variance } \\
\text { Range } \\
\text { Minimum } \\
\text { Maximum } \\
\text { Sum }\end{array}$ & $\begin{array}{c}25 \\
0 \\
62,96 \\
65,00 \\
66 \\
6,010 \\
36,123 \\
21 \\
52 \\
73 \\
1574\end{array}$ \\
\hline
\end{tabular}

Dari tabel di atas didapati bahwa distribusi skor jawaban tersebar dari skor terendah (minimum) 52 yang artinya nilai tersebut yang paling rendah dalam memotivasi guru ketika bekerja. Sedangkan skor tertinggi (maximum) 73 yang artinya nilai tersebut digunakan paling tinggi dalam memotivasi guru ketika bekerja. Jumlah (sum) dari skor tersebut adalah 1574. Berdasarkan distribusi 
skor pada tabel tersebut, diperoleh rata-rata (mean) sebesar 62,96; skor tengah (median) 65,00; data yang sering muncul (mode) 66; dan memiliki variansi (variance) 36,123; serta range 21. Untuk memperoleh gambaran yang jelas tentang distribusi skor, dapat dilihat pada tabel berikut.

Tabel 3 Distribusi Skor Motivasi Kerja

\begin{tabular}{|c|c|c|c|c|c|}
\hline & & Frequency & Percent & Valid Percent & $\begin{array}{c}\text { Cumulative } \\
\text { Percent }\end{array}$ \\
\hline \multirow[t]{16}{*}{ Valid } & 52 & 1 & 4,0 & 4,0 & 4,0 \\
\hline & 54 & 1 & 4,0 & 4,0 & 8,0 \\
\hline & 55 & 2 & 6,0 & 8,0 & 16,0 \\
\hline & 57 & 1 & 4,0 & 4,0 & 20,0 \\
\hline & 58 & 3 & 12,0 & 12,0 & 32,0 \\
\hline & 59 & 1 & 4,0 & 4,0 & 36,0 \\
\hline & 60 & 1 & 4,0 & 4,0 & 40,0 \\
\hline & 61 & 1 & 4,0 & 4,0 & 44,0 \\
\hline & 65 & 3 & 12,0 & 12,0 & 56,0 \\
\hline & 66 & 4 & 16,0 & 16,0 & 72,0 \\
\hline & 67 & 2 & 8,0 & 8,0 & 80,0 \\
\hline & 69 & 2 & 8,0 & 8,0 & 88,0 \\
\hline & 71 & 1 & 4,0 & 4,0 & 92,0 \\
\hline & 72 & 1 & 4,0 & 4,0 & 96,0 \\
\hline & 73 & 1 & 4,0 & 4,0 & 100,0 \\
\hline & Total & 25 & 100,00 & 10,00 & \\
\hline
\end{tabular}

Kemudian derajat pencapaian responden secara keseluruhan dapat kita peroleh pada variabel motivasi kerja dapat dilihat dari hasil pengukuran berikut:

$$
D P=\frac{\Sigma X}{N \times \text { Sitem } x \text { skala tertinggi }} \quad x 100 \%
$$




$$
\begin{aligned}
& =\frac{1574}{25 \times 16 \times 5} \times 100 \% \\
& =\frac{1574}{2000} \times 100 \% \\
& =0,787 \times 100 \% \\
& =78,7 \% \quad \text { (kategori cukup baik) }
\end{aligned}
$$

Dari perhitungan di atas didapatkan hasil pengukuran sebesar 78,7\%, maka derajat pencapaian variabel motivasi kerja guru di Sekolah Dasar termasuk kategori cukup

\begin{tabular}{|c|c|}
\hline \multirow{2}{*}{\multicolumn{2}{|c|}{ Statistic }} \\
\hline & \\
\hline Valid & 25 \\
\hline Missing & 0 \\
\hline Mean & 415,96 \\
\hline Median & 404,00 \\
\hline Mode & 464 \\
\hline Std. Deviation & 42,197 \\
\hline Variance & 1780,623 \\
\hline Range & 121 \\
\hline Minimum & 353 \\
\hline Maximum & 474 \\
\hline Sum & 10399 \\
\hline
\end{tabular}
baik.

\section{b. Deskripsi Data Kinerja Guru}

\section{Tabel 4 Deskripsi Data Variabel Kinerja Guru}

Dari tabel di atas didapati bahwa distribusi skor jawaban tersebar dari skor terendah (minimum) 353 yang artinya nilai tersebut yang paling rendah dalam mempengaruhi kinerja guru. Sedangkan skor tertinggi (maximum) 474 yang artinya nilai tersebut digunakan paling tinggi dalam mempengaruhi kinerja guru. Jumlah (sum) dari skor tersebut adalah 10399. Berdasarkan distribusi skor pada tabel tersebut, diperoleh ratarata (mean) sebesar 415,96; skor tengah (median) 404,00; data yang sering muncul (mode) 464; dan memiliki variansi (variance) 1780,623; serta range 121.

Untuk memperoleh gambaran yang jelas tentang distribusi skor, dapat dilihat pada tabel berikut: 
Tabel 5 Distribusi Frekuensi Skor Kinerja Guru

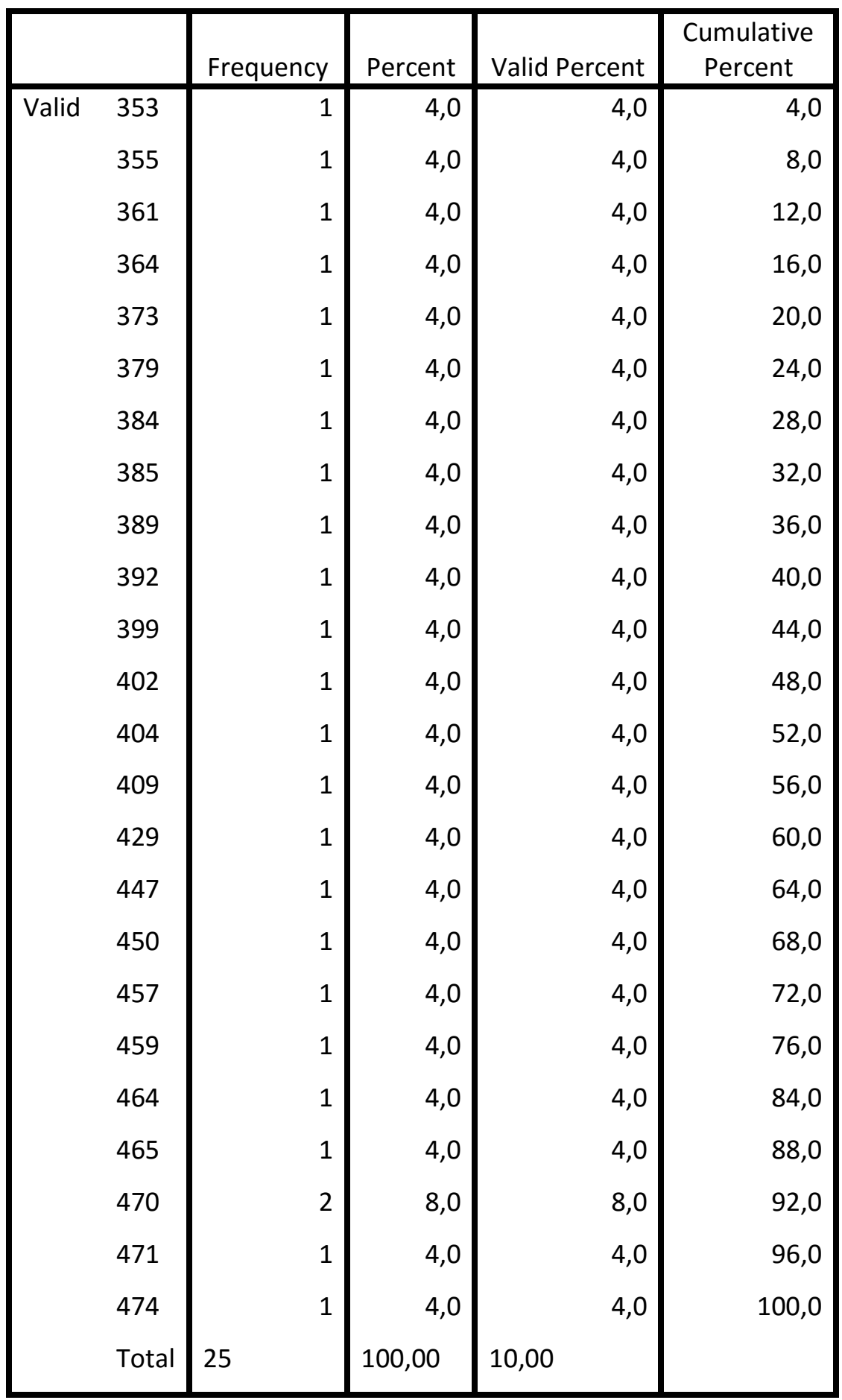

Kemudian derajat pencapaian responden secara keseluruhan dapat kita peroleh pada variabel motivasi kerja dapat dilihat dari hasil pengukuran berikut: 


$$
\begin{array}{rlr}
D P & =\frac{\sum X}{N x \text { Eitem } x \text { skala tertinggi }} \quad x 100 \% \\
& =\frac{10399}{25 \times 93 \times 5} \times 100 \% \\
& =\frac{10399}{11625} \times 100 \% \\
& =0,8945376344 \times 100 \% \\
& =89,57 \% \quad \text { (kategori baik) }
\end{array}
$$

Dari perhitungan di atas didapatkan hasil pengukuran sebesar $85,76 \%$, maka derajat pencapaian variabel motivasi kerja guru di Sekolah Dasar termasuk kategori baik

\section{Uji Prasyaratan Analisis}

Teknik pengujian pada hipotesis di dalam penelitian ini dilakukan dengan menggunakan analisis korelasi. Analisis ini dapat dilakukan apabila persyaratan-persyaratannya terpenuhi. persyaratannya antara lain uji normalitas data dan uji linearitas.

\section{a. Uji Normalitas}

Pengujian ini dilakukan dengan menggunakan uji Kolmogorov-
Smirnov (K-S) pada program SPSS 22 dimana distribusi data dapat dikatakan normal atau tidak apabila dalam pengambilan keputusannya berpedoman pada:

$$
\mathrm{H}_{0}=\text { Data berdistribusi }
$$

normal

$$
\mathrm{H}_{1}=\text { Data berdistribusi tidak }
$$

normal

Syarat pengambilan keputusan adalah sebagai berikut:

Tolak $\mathrm{H}_{0}$, jika Sig. $<0,05$

Terima $\mathrm{H}_{0}$, jika Sig. $\geq 0,05$

Hasil dari perhitungan uji normalitas dengan SPSS 22 dapat dilihat pada tabel berikut:

Tabel 6 Uji Normalitas

\begin{tabular}{|ll|r|r|}
\hline \multicolumn{3}{|c|}{ One-Sample Kolmogorov-Smirnov Test } \\
\hline $\mathbf{N}$ & & Motivasi Kerja & Kinerja Guru \\
Normal Parameters ${ }^{\mathrm{a}, \mathrm{b}}$ & Mean & 25 & 25 \\
& Std. Deviation & 62,96 & 415,96 \\
Most Extreme Differences & Absolute & 6,010 & 42,197 \\
& Positive &, 193 &, 169 \\
& Negative &, 115 &, 132 \\
Test Statistic &,- 193 &,- 169 \\
Asymp. Sig. (2-tailed) & &, 193 &, 169 \\
& &, $017^{\mathrm{c}}$ & $064^{\mathrm{c}}$ \\
\hline
\end{tabular}

a. Test distribution is Normal.

b. Calculated from data.

c. Lilliefors Significance Correction. 
Dari tabel hasil uji normalitas tersebut dapat dilihat bahwa skor signifikansi nilai motivasi kerja sebesar 0,017. Sedangkan skor signifikansi pada nilai kinerja guru sebesar 0,064. Maka dapat disimpulkan bahwa variabel-varibel tersebut berdistribusi normal.

c. Uji Linearitas

Pengujian linearitas dalam penelitian ini dilakukan untuk melihat apakah variabel data motivasi kerja membentuk garis linear terhadap variabel kinerja guru atau tidak. Pengujian linearitas dengan menggunakan uji Anova (analysis of varians) melalui program SPSS 22. Hipotesis untuk persyaratan uji linearitas adalah sebagai berikut:

$$
\mathrm{H}_{0}=\text { Sebaran data variabel }
$$
bebas $(\mathrm{X})$

membentuk garis linear terhadap variabel terikat (Y). $\mathrm{H}_{1}=$ Sebaran data variabel bebas $(\mathrm{X})$

tidak membentuk garis linear terhadap variabel terikat (Y).

Untuk dasar pengambilan keputusan, maka digunakan pedoman sebagai berikut:

Tolak $\mathrm{H}_{0}$, jika tidak signifikansi (deviaton from linearity) $\leq$ Alpha 0,05

Terima $\mathrm{H}_{0}$, jika signifikansi (deviaton from linearity) > Alpha 0,05

Hasil uji linearitas dapat dilihat pada Tabel berikut:

Tabel 7 Hasil Uji Linearitas

\begin{tabular}{|c|c|c|c|c|c|c|c|}
\hline & & & $\begin{array}{l}\text { Sum of } \\
\text { Squares }\end{array}$ & $\mathrm{df}$ & $\begin{array}{l}\text { Mean } \\
\text { Square }\end{array}$ & $\mathrm{F}$ & Sig. \\
\hline $\begin{array}{c}\text { Kinerja Guru } \\
*\end{array}$ & Between & (Combined) & 26457,127 & 15 & 1889,795 & 1,161 & 415 \\
\hline \multirow{4}{*}{$\begin{array}{l}\text { Motivasi } \\
\text { Kerja }\end{array}$} & Groups & Linearity & 22881,978 & 1 & 22881,978 & 14,057 & ,004 \\
\hline & & $\begin{array}{c}\text { Deviation from } \\
\text { Linearity }\end{array}$ & 3575,149 & 13 & 275,011 & 169 & 998 \\
\hline & Within Groups & & 16277,833 & 10 & 1627,783 & & \\
\hline & Total & & 42734,960 & 24 & & & \\
\hline
\end{tabular}

Berdasarkan nilai tabel di atas, taraf signifikansi yang diperoleh sebesar 0,998. Sedangkan pedoman signifikansi sebesar 0,05; artinya nilai signifikansi $0,998>0,05$ maka $\mathrm{H}_{0}$ diterima. Dengan demikian dapat dinyatakan bahwa sebaran data pada variabel motivasi kerja memiliki hubungan yang linear atau garis linear dengan kinerja guru.

\section{Pengujian Hipotesis}

Berikut ini adalah pengujian hipotesis yang menggunakan aplikasi SPSS 22 dengan hasil sebagai berikut: 


\section{Tabel 8 Uji Korelasi}

Correlations

\begin{tabular}{|cc|c|c|}
\hline & & Motivasi Kerja & Kinerja Guru \\
\hline Motivasi Kerja & Pearson Correlation & 1 &, $732^{* *}$ \\
& Sig. (2-tailed) & &, 000 \\
& N & 25 & 25 \\
Kinerja Guru & Pearson Correlation &, $732^{* *}$ & 1 \\
& Sig. (2-tailed) &, 000 & \\
& N & 25 & 25 \\
\hline
\end{tabular}

**. Correlation is significant at the 0.01 level (2-tailed).

Dapat dilihat pada hasil perhitungan di atas bahwa harga korelasi (rhitu ) sebesar 0,729 pada skor motivasi kerja dan kinerja guru. Interpretasi koefisien korelasi dalam penelitian ini pada kategori kuat. Selanjutnya untuk mengetahui seberapa besar pengaruh dan untuk melihat tingkat signifikansi dilakukan dengan menggunakan uji t.Hipotesis untuk persyaratan uji t adalah: $\mathrm{H}_{0}=$ Tidak terdapat pengaruh signifikan antara motivasi kerja dengan kinerja guru
$\mathrm{H}_{1}=$ Terdapat pengaruh signifikan antara motivasi kerja dengan kinerja guru

Untuk dasar pengambilan keputusan uji t adalah sebagai berikut:

Tolak H0, jika $t_{\text {hitung }} \geq t_{\text {tabel }}$

Terima $\mathrm{H} 0$, jika $t_{\text {hitung }} \geq t_{\text {tabel }}$

Kemudian untuk mencari uji $t$ dengan perhitungan manual maka digunakan rumus sebagai berikut:

$$
\begin{aligned}
t_{\text {hitung }} & =\frac{\mathrm{r} \cdot \sqrt{\mathrm{n}-2}}{\sqrt{1-r^{2}}} \\
& =\frac{0,732 \sqrt{25-2}}{\sqrt{1-0,732^{2}}} \\
& =\frac{0,732 \sqrt{25-2}}{\sqrt{1-0,535824}} \\
& =\frac{0,732.4,769}{\sqrt{0,464176}} \\
& =\frac{3,510672}{0,6813046308} \\
& =5,1529
\end{aligned}
$$

Dari hasil peritungan di atas, diperoleh hasil thitung sebesar 5,1529. Setelah nilai thitung didapatkan, maka langkah selanjutnya adalah mencari nilai tabel dengan Alpha 
0,05 dan derajat kebebasan $(\mathrm{df}=\mathrm{N}-2)$. Maka, diperoleh $t_{\text {tabel }}$ sebesar 2,068. Dari hasil tersebut barulah kita dapat membandingkannya antara thitung dengan $t_{\text {tabel }}$ dengan dasar pengambilan keputusan bahwa thitung $(7,4618) \geq t_{\text {tabel }}(2,068)$, maka $\mathrm{H}_{0}$ ditolak dan $\mathrm{H}_{1}$ diterima. Dengan demikian pada penelitian ini terbukti bahwa terdapat hubungan signifikan antara motivasi kerja dengan kinerja guru di Sekolah Dasar.

Berdasarkan hasil deskripsi data variabel motivasi kerja guru di Sekolah Dasar memperoleh skor tertinggi (maximum) 73, skor terendah (minimum) 52 , dan nilai rata-rata 62,96 yang berada pada kategori sedang. Sehingga dengan demikian, guru yang memiliki motivasi kerja sedang merupakan guru yang masih kurang memiliki semagat dalam melaksanakan pekerjaannya. Motivasi kerja merupakan komponen terpenting bagi guru karena motivasi kerja merupakan trigger atau pemicu guru dalam melaksanakan kewajibannya sebagai seorang guru. Guru dapat mengajukan pendapat seputar kegiatan belajar mengajar di sekolah kepada kepala sekolah demi memompa motivasi kerjanya. Seperti memberikan penghargaan guru teladan setiap tahunnya dengan imbalan hadiah tertentu. Kepala sekolah pemimpin juga bisa menjadi tempat para guru dalam meminta pendapat maupun mencari solusi atas masalah yang sedang dihadapi sehingga motivasi guru dapat meningkat kembali. Sedangkan variabel kinerja guru memperoleh skor tertinggi skor tertinggi (maximum) 474, skor terendah (minimum) 353 , dan nilai rata-rata 415,96 yang berada pada kategori sedang. Dengan demikian guru yang memiliki kinerja sedang merupakan guru yang memiliki kinerja cukup rendah. Kinerja guru merupakan komponen yang mempengaruhi kualitas hasil kegiatan belajar mengajar. Semakin tinggi kinerjanya maka semakin baik pula kualitas hasil kegiatan belajar mengajarnya. Sebaliknya semakin rendah kinerjanya makan semakin rendah pula kualitas hasil kegiatan belajar mengajarnya. Demi meningkatkan kinerja guru, maka kepala sekolah dapat memaksimalkan pengadaan sarana dan prasarana sekolah dalam menunjang proses kegiatan belajar mengajar. Kepala sekolah juga dapat memberikan bonus bagi guru yang mampu meningkatkan kinerjanya.

\section{KESIMPULAN}

Dari beberapa indikator yang mempengaruhi kinerja guru, pada penelitian ini difokuskan pada tiga variabel yaitu Kinerja guru dapat ditingkatkan melalui upaya peningkatan motivasi kerja mereka. Peningkatan motivasi kerja dapat dilakukan melalui: 1. Achievment of Motivation (motivasi akan prestasi) 2. Afiliation of Motivation (motivasi akan kerja sama) 3. Power of Motivation (motivasi akan kekuasaan). Peningkatan motivasi kerja guru itu penting dalam pelaksanaan proses kegiatan belajar mengajar sehingga kinerja guru dapat maksimal dan berimplikasi pada meningkatnya kualitas peserta didik.

\section{DAFTAR PUSTAKA}

Dale H. Schunk, dkk., (2012) Motivasi dalam Pendidikan: Teori, Penelitian, dan Aplikasi. Jakarta: PT Indeks.

Djamarah, Syaiful Bahri. 2011. Psikologi Belajar. Jakarta: Rineka Cipta.

Jamaris, Martini. (2013). Orientasi dalam Psikologi Pendidikan. Bogor: Galia Indonesia.

Komang Wiwin Sri Widiastuti dkk. (2013), Pengaruh Kompetensi Profesional Dan Motivasi Kerja Terhadap Kinerja Guru Di Smk Triatma Jaya 
Singaraja Tahun Ajaran 2012/2013. Jurnal Pendidikan

Ekonomi Undiksha Vol 3, No 1 (2013).

DOI: http://dx.doi.org/10.23887/jjpe .$v 3 \mathrm{i} 1.1280$

Mulyasa. (2012). Standar Kompetensi dan Sertifikasi Guru. Bandung: Remaja Posdakarya.

Sugiyono, (2009) Metode Penelitian Kuantitatif Kualitatif dan R\&D, Bandung: Alfabeta.

Sugiyono. (2009). Metode penelitian pendidikan, pendekatan kuantitatif, kualitatif, dan R \& D. Bandung: Alfabeta.

Sahertien, Piet A. (2010). Konsep Dasar dan Teknik Supervisi Pendidikan Dalam Rangka Mengembangkan Sumber Daya Manusia. Jakarta: Rineka Cipta.

Supardi. (2013). Kinerja Guru. Jakarta: Rajawali Pers.

Sukmadinata, N. S. (2007) Landasan psikologi proses pendidikan. Bandung: Remaja Rosdakarya.
Supriyatin, (2013) Manajemen Sumber Daya Manusia, Jakarta: CV. Mitra Kreatif Solusindo.

Suyanto dan Hisyam D.(2000). Refleksi dan reformasi pendidikan di Indonesia memasuki millennium III. Yogyakarta: Adi Cita.

Usman, Husaini dan Purnomo Setiady Akbar. (2011). Pengantar Statistika. Jakarta: Bumi Aksara.

Uno, Hamzah B. (2010). Teori Motivasi dan Pengukurannya; Analisis Di Bidang Pendidikan. Jakarta: Bumi Aksara.

Widiastuti, Wiwin, S., K., Haris, I, A., \& Suharsono, N. (2013). Pengaruh Kompetensi Profesional dan Motivasi Kerja terhadap Kinerja Guru di SMK Triatma Jaya Singaraja Tahun Ajaran 2012/2013. Jurnal Undiksha, Vol. 3, No. 1. Diambil pada tanggal 15 Mei 2017 dari situs World Wide Web: http://ejournal.undiksha.ac.id/ index.php/JJPE/article/view/1280 /1141 